\title{
Analisis Pemecahan Masalah Berdasarkan Teori Pemrosesan Informasi
}

\author{
Nurhayati ${ }^{1}$, Nizlel Huda ${ }^{2}$, Suratno $^{3}$ \\ ${ }^{1}$ Mahasiswa Pascasarjana Universitas Jambi, Indonesia \\ ${ }^{2}$ Dosen Pascasarjana Universitas Jambi, Indonesia \\ ${ }^{3}$ Dosen Pascasarjana Universitas Jambi, Indonesia \\ Correspondance email: inuyn@yahoo.co.id
}

\begin{abstract}
Abstrak. Tujuan dari penelitian ini untuk mendeskripsikan proses berpikir siswa dalam menyelesaikan masalah matematika berdasarkan teori pemrosesan informasi. Penelitian ini merupakan penelitian deskriptif dengan pendekatan kualitatif yang menggunakan teknik pengumpulan data dengan menggunakan metode think aloud dan wawancara. Instrumen dalam penelitian ini menggunakan soal tes tertulis dan pedoman wawancara. Subjek dalam penelitian ini terdiri dari satu orang berkemampuan tinggi, satu siswa berkemampuan sedang dan satu siswa berkemampuan rendah. Hasil penelitian menunjukkan bahwa informasi atau stimulus berupa soal yang diterima siswa yang berkemampuan matematika tinggi, sedang, dan rendah masuk ke sensory register melalui indra penglihatan dan indra pendengaran. Kemudian attention terjadi setelah membaca soal dan timbul perception. Selanjutnya, siswa merealisasikan perception dengan melakukan retrieval konsep yang dibutuhkan dari long term memory untuk menyelesaikan masalah. Ketika melakukan retrieval siswa yang berkemampuan matematika sedang, terdapat seorang siswa yang mengalami kesalahan atau retrieval failure dalam menjelaskan konsep. Kemudian bagi siswa yang berkemampuan matematika rendah, konsep-konsep yang dibutuhkan short term memory tidak tersimpan dengan baik oleh long term memory, sehingga siswa sering mengalami kesalahan dan lupa.
\end{abstract}

Kata Kunci: Pemecahan Masalah, Teori Pemrosesan Informasi

\begin{abstract}
The purpose of this study is to describe students' thought processes in solving mathematical problems based on information processing theory. This research is a descriptive study with a qualitative approach that uses data collection techniques using the method of think aloud and interviews. The instrument in this study used written test questions and interview guidelines. The subjects in this study consisted of one high ability person, one moderate ability student and one low ability student. The results showed that information or stimulus in the form of questions received by students with high, medium, and low mathematical abilities entered the sensory register through the sense of sight and sense of hearing. Then attention occurs after reading the problem and perception arises. Next, students realize perception by retrieval the concepts needed from long term memory to solve problems. When conducting a retrieval of students with moderate mathematical abilities, there is a student who experiences a retrieval failure in explaining the concept. Then for students who have low mathematical ability, the concepts needed for short term memory are not stored well by long term memory, so students often experience errors and forget.
\end{abstract}

Keywords: Problem Solving, Information Processing Theory

\section{PENDAHULUAN}

Pada hakikatnya, matematika merupakan ilmu dengan berbagai materi yang dapat memicu berkembangnya kemampuan berpikir. Ngilawajan menyatakan bahwa proses yang terjadi dalam aktivitas belajar siswa melibatkan proses mental yang terjadi dalam otak, sehingga belajar merupakan aktivitas yang selalu terkait dengan proses berpikir. Pembelajaran matematika adalah proses belajar mengajar yang dibangun oleh guru untuk mengembangkan kreativitas berpikir peserta didik yangdapat meningkatkan kemampuan berpikir peserta didik, serta meningkatkan kemampuan mengkonstruksi pengetahuan baru sebagai upaya meningkatkan penguasaan yang baik terhadap materi matematika (Susanto, 2013).

Salah satu cara untuk merangsang proses berpikir siswa adalah dengan memberikan siswa sebuah masalah dalam belajar matematika. Menurut Indah (2016), pemecahan masalah adalah proses menerapkan pengetahuan yang telah diperoleh sebelumnya ke dalam situasi baru yang belum dikenal. Hal ini menjadikan suatu masalah bagi seseorang belum tentu merupakan masalah bagi orang lain karena setiap siswa mengetahui prosedur dan pengetahuan yang ada dalam diri siswa untuk menyelesaikannya. Menurut Syaiful (2019), pemecahan masalah membantu siswa lebih memahami matematika secara keseluruhan dan membuat matematika lebih bermakna. Oleh karenanya, proses berpikir siswa dalam menyelesaikan masalah matematika dapat diketahui berdasarkan langkah-langkah yang dilakukan siswa dalam penyelesaian masalah.

Salah satu teori yang mengkaji tentang proses berpikir siswa adalah teori pemrosesan informasi. Menurut Solso (2008) teori pemrosesan informasi merupakan teori yang menekankan pada proses memori dan proses berpikir 
(thinking). Teori pemrosesan informasi terdiri dari beberapa komponen, yaitu komponen penyimpanan informasi dan komponen proses kognitif. Komponen penyimpanan informasi terdiri dari sensory register (registor pengindraan), short term memory (memori jangka pendek), dan long term memory (memori jangka panjang). Sedangkan komponen proses kognitif yaitu attention, perception (persepsi), retrieval (memanggil kembali), rehearsal (pengulangan), dan encoding (penguatan). Dalam Pemecahan masalah, informasi yang diperoleh yaitu berupa soal atau maslah matematika yang akan diselesaikan (Ammamah, 2016).

Berdasarkan uraian di atas, penting untuk mendeskripsikan proses pemecahan masalah siswa berdasarkan teori pemrosesan informasi untuk mengetahui alur berpikir siswa. Dengan demikian, peneliti mengadakan penelitian yang berjudul "Analisis Pemecahan Masalah Berdasarkan Teori Pemrosesan Informasi”.

\section{LANDASAN TEORI}

\section{Pengertian Pemecahan Masalah}

Imelda (2018) suatu pertanyaan akan menjadi masalah hanya jika pertanyaan itu menunjukkan adanya suatu tantangan yang tidak dapat dipecahkan oleh prosedur rutin yang sudah diketahui pelaku. Menurut Novriani (2017), masalah adalah pekerjaan di mana seorang individu yang menghadapinya merasakan kebutuhan untuk menyelesaikan atau ingin menyelesaikannya, dia tidak memiliki cara bagaimana menyelesaikannya dan dia mencoba untuk menyelesaikannya.

Menurut Wang (2010), pemecahan masalah adalah proses kognitif otak yang mencari atau menyimpulkan solusi untuk masalah yang diberikan dalam bentuk serangkaian jalur untuk mencapai serangkaian tujuan yang diharapkan.

Langkah-langkah menurut Polya (Polya, 1973, Liljedal, 2016) yaitu sebagai berikut:

1. Memahami Masalahnya

Siswa sering gagal dalam memecahkan masalah karena siswa tidak mampu memahami masalah yang diberikan. Untuk dapat memahami masalah maka langkah-langkah yang bisa digunakan siswa sebagai berikut:

a. Apa yang tidak diketahui? Apa datanya? Apa kondisinya?

b. Apakah mungkin informasi dalam soal yang diketahui memenuhi persyaratan solusi penyelesaiannya? Apakah informasi yang ada cukup untuk menentukan yang tidak diketahui? Atau tidak cukup? Atau bertentangan?

c. Pisahkan berbagai bagian data. Bisakah siswa menuliskannya?

2. Menyusun Rencana

Hal-hal yang perlu diperhatikan dalam menyusun rencana yaitu melihat kembali data saat siswa memahami masalah, Siswa harus menemukan keterkaitan antar data apakah data tersebut sudah cukup untuk menyelesaikan masalah atau perlu tambahan data tambahan untuk menyelesaikannya. Pada saat tingkat ini siswa tidak boleh keliru dalam menyusun rencana agar pemecahan masalah yang dilakukan siswa tepat.

3. Melaksanakan Rencana

Untuk mencari penyelesaian yang tepat maka rencana yang disusun harus dilaksanakan dengan teliti dan tepat. Langkah ini lebih mudah dari langkah sebelumnya karena siswa melaksanakannya sesuai dengan rencana yang telah disusun sebelumnya.

4. Melihat Kembali

Langkah terakhir, periksalah solusi yang telah diperoleh, apakah cara yang digunakan sudah tepat dan apakah dapat kekeliruan dalam penyelesaiannya.

\section{Teori Pemrosesan Informasi}

Teori pemrosesan informasi merupakan teori belajar yang dicetuskan oleh Robert Gagne. Teori ini merupakan gambaran atau model dari kegiatan di dalam otak manusia saat memproses suatu informasi. Menurut Putra (2014) dalam teori pemrosesan informasi terdapat tiga komponen utama, yaitu komponen penyimpanan informasi, komponen proses kognitif, dan komponen proses kontrol. Ketiga komponen tersebut bekerja saling melengkapi. Ketiga komponen utama tersebut adalah sebagai berikut:

1. Komponen Penyimpanan Informasi

Komponen penyimpanan informasi merupakan tempat-tempat penyimpanan informasi. Adapun komponen penyimpanan informasi yang bekerja saat pemrosesan informasi adalah sensory register, short term memory, dan long term memory

2. Komponen Proses Kognitif

Komponen proses kognitif merupakan komponen yang bekerja saat terjadinya pemrosesan informasi. Komponen proses kognitif terdiri dari attention, perception, retrieval, rehearsal, dan encoding.

3. Komponen Proses Kontrol

Fungsi utama dari komponen proses kontrol adalah menentukan proses informasi tertentu yang diperlukan untuk mengerjakan suatu tugas. Dengan kata lain, untuk menentukan pendekatan dari individu untuk satu atau lebih 
pemrosesan informasi tentang bagaimana mereka akan memilih dan menyimpan informasi serta retrieving dan encoding informasi tersebut. Dengan demikian, komponen proses kontrol dapat diartikan sebagai strategi (metakognisi) seseorang dalam melakukan suatu pemrosesan informasi.

\section{METODE PENELITIAN}

Penelitian ini menggunakan metode penelitian kualitatif deskriptif. Penelitian kualitatif bertujuan untuk mengembangkan eksplorasi mendalam dari sebuah fenomena, bukan untuk menggeneralisasi populasi (Creeswell, 2012). Subjek dalam penelitian ini yaitu siswa SMP N 1 Kota Jambi. Subjek penelitian ini dipilih dengan pertimbangan tertentu. Dalam tujuan pemilihan subjek, peneliti sengaja memilih individu yang paham dengan fenomena yang akan diteliti. Menurut Patton dalam (Creeswell, 2012) standar yang digunakan dalam memilih subjek adalah apakah mereka kaya akan informasi. Dalam penelitian ini yang menjadi pertimbangan dalam pemilihan subjek yaitu subjek sudah mempelajari materi lingkaran dan subjek yang mampu memberikan informasi sebanyak mungkin.

Dalam penelitian kualitatif ini, yang menjadi kunci instrument penelitian adalah peneliti itu sendiri (Bogdan, 1982). Alasannya bahwa segala sesuatunya belum mempunyai bentuk yang pasti. Masalah, fokus penelitian, prosedur penelitian, hipotesis yang digunakan, bahkan hasil yang diharapkan, itu semuanya tidak dapat ditentukan secara pasti dan jelas sebelumnya. Segala sesuatu masih perlu dikembangkan sepanjang penelitian itu. Instrumen lainnya adalah audiovisual dan wawancara tidak terstruktur untuk mengungkap proses berpikir pemecahan masalah siswa.

\section{HASIL DAN PEMBAHASAN}

Data yang disajikan diperoleh dari penelitian yang dilakukan terhadap 3 subjek dari 3 kelompok. S1 dari kelompok kemampuan pemecahan masalah tinggi, S2 dari kelompokkemampuan pemecahan masalah sedang dan S3 dari kelompok kemampua pemecahan masalah rendah. Subjek yang terpilih diminta untuk mengerjakan soal tes tulis dengan menggunakan metode think aloud dan kemudian dilakukan wawancara kepada masing-masing subjek. Soal tes tertulis yang digunakan peneliti untuk mengungkapkan proses penyelesaian masalah berdasarkan teori pemrosesan informasi sebagai berikut :

Dua buah lingkaran yang masing-masing berjari-jari $10 \mathrm{~cm}$ diletakkan pada sebuah bidang datar dengan kedua lingkaran saling bersinggungan satu sama lain. Sebuah lingkaran kecil

diletakkan di antara kedua lingkaran besar tersebut sedemikian hingga lingkaran kecil menyinggung kedua lingkaran besar dan bidang datar. Berapakah jari-jari lingkaran kecil?

\section{Deskripsi Data}

1. Deskripsi Data $\mathrm{S} 1$

Berikut adalah Jawaban tertulis subjek S1

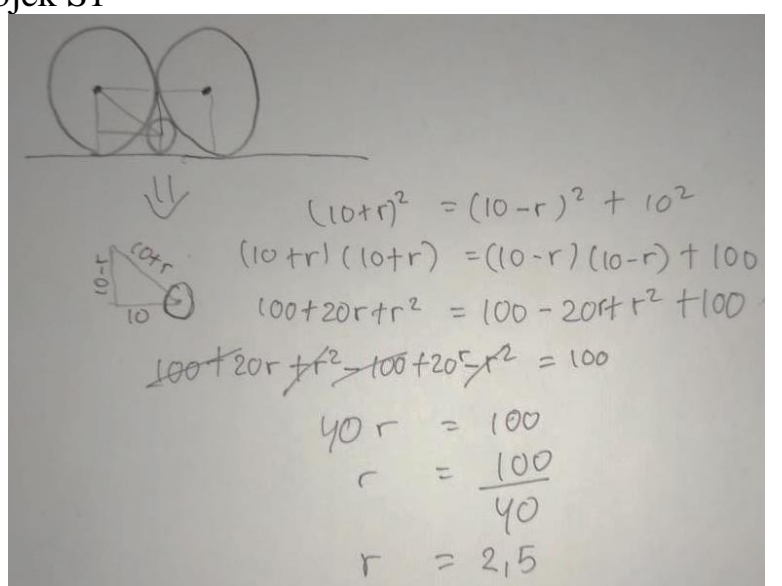

Gambar 1 Jawaban S1

Berdasarkan gambar 1 terlihat bahwa S1 mampu memodelkan informasi yang ada pada soal dalam bentuk gambar. S1 kemudian menghubungkan antar setiap titik pusat sehingga diperoleh gambar segitiga yang diketahui panjang setiap sisinya. Dari jawaban S1 diperoleh sisi depan $10-r$, sisi alas 10 dan sisi miring $10+r$. Selanjutnya S1 menggunakan rumus phytagoras untuk menjawab soal tersebut sehingga diperoleh panjang jari-jari lingkaran kecil yaitu 2,5 .

Berikut ini disajikan pernyataan yang diungkapkan oleh S1 ketika menyelesaikan soal :

(Membaca Soal) Dua buah lingkaran yang masing-masing berjari-jari $10 \mathrm{~cm}$ diletakkan pada sebuah bidang datar dengan kedua lingkaran saling bersinggungan satu sama lain (menggambarkan garis lurus sebagai 
bidang datar dan 2 buah lingkaran yang saling bersinggungan). Sebuah lingkaran kecil diletakkan di antara kedua lingkaran besar tersebut sedemikian hingga lingkaran kecil menyinggung kedua lingkaran besar dan bidang datar (membuat lingkaran kecil yang bersinggungan dengan 2 buah lingkaran besar dan bidang datar). Di sini terdapat tititk pusat (membuat titik pusat pada 3 lingkaran). Ditarik garis dari titik pusan ke lingkaran. Karena jari-jari lingkaran besar 10 maka panjang ini 10 (menuliskan panjang jari-jari). Buat garis lagi untuk lingkaran besar dan kecil. Misal jari-jari lingkaran kecil $r$ jadinya disini 10 $+r$ (sisi miring), disini 10-r (sisi depan) terakhir yang ini tetap 10 (sisi alas). Masukkan ke teorema phytagoras sehingga,

$$
\begin{aligned}
& (10+r)^{2}=(10-r)^{2}+10^{2} \\
& (10+r)(10+r)=(10-r)(10-r)-100 \\
& 100+20 r+r^{2}=100-20 r+r^{2}+100 \\
& 100+20 r+r^{2}-100-20 r-r^{2}=100\left(\text { coret } 100 \text { di ruas kiri dan } r^{2}\right) \\
& 40 r=100 \\
& r=\frac{100}{40} \\
& r=2,5
\end{aligned}
$$

Jadi hasil jari-jari lingkaran kecil 2,5.

2. Deskripsi data $\mathrm{S} 2$

Berikut adalah jawaban tertulis subjek S2

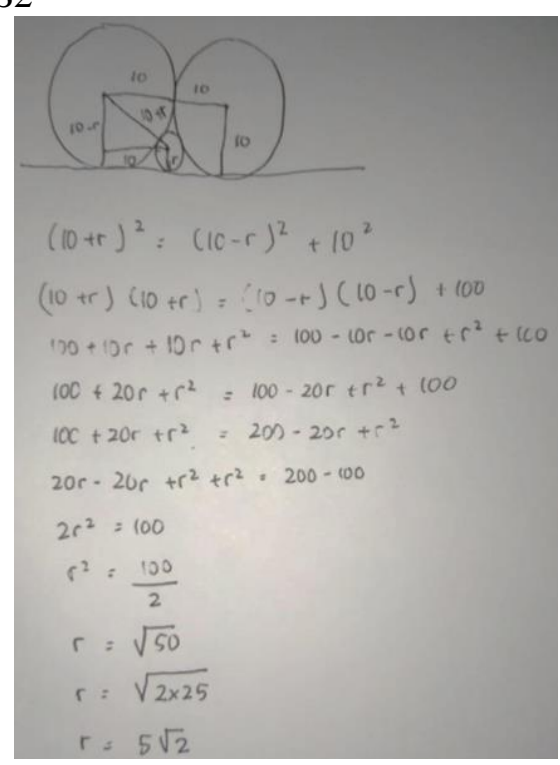

Gambar 2 Jawaban S2

Berdasarkan gambar 2, dapat dilihat bahwa S2 memodelkan soal ke dalam bentuk gambar. S2 membuat 2 buah lingkaran besar, bidang datar dan lingkaran kecil yang saling bersinggungan. Dari gambar tersebut diperoleh gambar segitiga siku-siku yang panjang sisi miringnya 10+r, sisi depan 10-r dan alas 10. Selanjutnya S2 menyelesaikannya dengan phytagoras namun penyelesaian yang dikerjakan oleh S2 tidak tepat.

Berikut ini disajikan pernyataan yang diungkapkan oleh S2 ketika menyelesaikan pemecahan masalah :

(Membaca soal) sebelum menyelesaikan soal ini. Perlu dibuat dulu gambarnya. Dua buah lingkaran yang masing-masing berjari-jari $10 \mathrm{~cm}$ diletakkan pada sebuah bidang datar dengan kedua lingkaran saling bersinggungan satu sama lain. Jadi disini ada dua lingkaran yang bersinggungan (membuat gambar lingkaran). Terus ada bidang datar juga yang bersingungan (membuat garis lurus sebagai bidang datar). Sebuah lingkaran kecil diletakkan di antara kedua lingkaran besar tersebut sedemikian hingga lingkaran kecil menyinggung kedua lingkaran besar dan bidang datar. Terus ada lingkaran kecil ditengah-tengah sini (membuat gambar lingkaran kecil diantara 2 lingkaran besar dan saling bersingungan). Ada titik pusat (membuat titik pusat dari ketiga lingkaran) terus tarik garis dari pusat ke lingkaran. Yang diketahui jari-jari lingkaran besar $10 \mathrm{~cm}$ jadi disini 10, disini juga 10 (membuat panjang jari-jari besar). Terus yang ditanya jarijari lingkaran kecil. Dimisalkan jari-jari lingkran kecil ini $r$ terus dihubungkan dengan lingkaran besar. Ini 
kepotong jadinya 10-r (sisi depan) yang ini jaraknya sama dengan diatas jadi 10 (alas) dan yang ini memanjang jadinya 10+r (sisi miring). Ini bentuknya segitiga siku-siku jadi menggunakan phytagoras

$$
\begin{aligned}
& (10+r)^{2}=(10-r)^{2}+10^{2} \\
& (10+r)(10+r)=(10-r)(10-r)+100 \\
& 100+10 r+10 r+r^{2}=100-10 r-10 r+r^{2}+100 \\
& 100+20 r+r^{2}=100-20 r-r^{2}+100 \\
& 100+20 r+r^{2}=200-20 r-r^{2} \\
& 20 r-20 r+r^{2}+r^{2}=200-100 \\
& 2 r^{2}=100 \\
& r^{2}=\frac{100}{2} \\
& r=\sqrt{50} \\
& r=\sqrt{2 \times 25} \\
& r=5 \sqrt{2}
\end{aligned}
$$

3. Deskripsi Data S3

Berikut adalah jawaban tertulis subjek S3

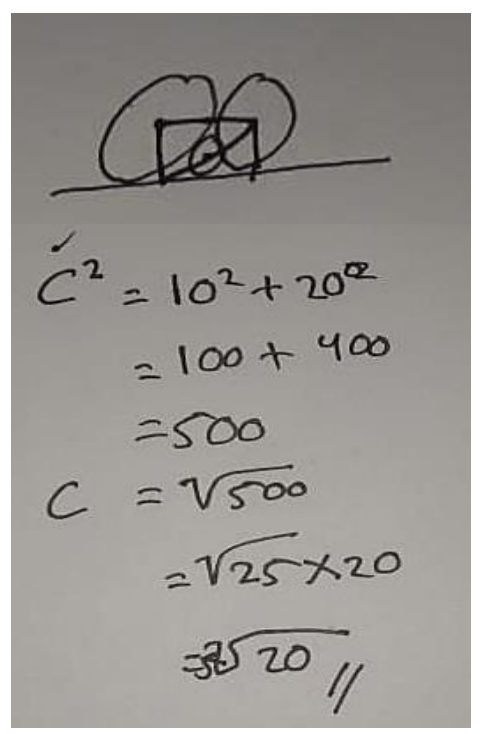

Gambar 3 Jawaban S3

Pada gambar ke 3 dapat di lihat bahwa S3 memodelkan ke dalam bentuk gambar. Dari informasi yang telah di simpan maka S3 membuat gambar yang sesuai dengan informasi yang dimilikinya. Dari gambar tersebut S3 membuat unsur-unsur dari lingkaran yaitu titik pusat dan jari-jari. Namun terjadi kesalahan ketika S3 menghubungkan jari-jari lingkaran kecil dan lingkaran besar.

Berikut ini disajikan pernyataan yang diungkapkan oleh S3 ketika menyelesaikan pemecahan masalah :

(Membaca soal) ada 2 lingkaran yang berjari-jari $10 \mathrm{~cm}$ yang saling bersinggungan satu sama lain dan juga bidang datar (membuat gambar 2 lingkaran besar dan bidang datar) lalu ada lingkaran kecil juga (membuat lingkaran kecil diantara 2 lingkaran besar dan bidang datar). Jadi disini ada titik pusat (menggambar titik pusat ketiga lingkaran) lalu tarik garis (membuat garis penghubung di setiap titik pusat) jadinya persegi panjang. Terus di garis ditengah jadi segitiga siku-siku. Lalu dikerjakan dengan menggunakan rumus phytagoras jadi $c^{2}=10^{2}+20^{2}$

$=100+400$

$=500$

$c=\sqrt{500}$

$=\sqrt{25 \times 20}$

$=5 \sqrt{20}$

Panjang jari-jari kecilnya $=5 \sqrt{20}$

\section{Pembahasan}


Teori pemrosesan informasi merupakan teori yang menekankan pada proses memori dan proses berpikir siswa. Dalam penelitian ini, proses berpikir siswa yang berkemampuan matematika tinggi dimulai dari adanya informasi (stimulus) berupa masalah geometri. kemudian mulai melakukan proses retrieval (pemanggilan kembali) untuk membuat suatu kesimpulan atau respon berupa hasil jawaban. Dalam proses menyelesaikan masalah, semua komponen dari teori pemrosesan informasi harus bekerja dengan baik agar dapat menghasilkan kesimpulan atau respon yang benar terutama komponen attention, perception, dan long term memory. Hal ini sesuai dengan pendapat Lunenburg dan Green yang menyatakan bahwa komponen attention, perception, dan long term memory merupakan landasan berpikir bagi siswa. Sehingga ketiga komponen tersebut memegang peranan penting dalam proses menyelesaikan masalah. Tahap pertama yang dilakukan oleh S1 dalam menyelesaikan masalah berdasarkan teori pemrosesan informasi adalah attention. Pada tahap attention, siswa yang berkemampuan matematika tinggi menerima informasi (stimulus) dengan mengamati dan membaca soal yang diberikan. Kemudian informasi atau stimulus berupa soal tersebut secara utuh masuk ke dalam sensory register melalui receptors yaitu indra penglihatan ataupun indra pendengaran. Menurut (Ngilawajan, 2013) membaca soal dengan cermat dan teliti menunjukkan bahwa subjek memberi perhatian terhadap informasi sehingga dapat dipahami dan diingat. Memberi perhatian merupakan cara untuk memindahkan informasi dari sensory register ke dalam short term memory. Dengan adanya perhatian maka subjek mampu mengidentifikasi masalah sehingga mampu menyatakan apa yang diketahui dan ditanyakan dari soal yang diberikan.

Setelah siswa mampu mengidentifikasi masalah dan mendapatkan informasi yang cukup maka siswa akan memberikan perception (persepsi) terhadap informasi. Siswa yang berkemampuan matematika tinggi mempunyai persepsi bahwa yang harus dilakukan setelah membaca soal adalah memodelkan soal kedalam bentuk gambar dan mengetahui panjang sisi-sisi yang dibutuhkan. Pada tahap ini yang dilakukan oleh S1 benar. Hal ini karena S1 sudah mempunyai pengetahuan dan pengalaman untuk menyelesaikan masalah. Hal ini sejalan dengan pendapat Gagne bahwa pengalaman dan pengetahuan yang tersimpan di long term Setelah dari sensory register, informasi selanjutnya memasuki short term memory. Di dalam short term memory, informasi yang telah diperoleh berdasarkan seleksi attention (perhatian) akan diolah lebih lanjut. Informasi lama berupa pengetahuan atau konsep-konsep yang dibutuhkan dalam menyelesaikan masalah dipanggil dari long term memory menuju short term memory. Proses pemanggilan kembali informasi inilah yang dimaksud dengan retrieval. Menurut Matlin (2009) long term memory memiliki kapasitas besar dan berisi ingatan dari pengalaman dan informasi tersebut telah terakumulasi seumur hidup. Menurut Jeneson (2012), long term memory mengacu pada informasi yang di peroleh dari masa lalu. Berdasarkan wawancara yang dilakukan rumus-rumus tersebut sudah ada sejak SD.

Ketika informasi (stimulus) meninggalkan short term memory, maka ada dua kemungkinan yang terjadi yaitu informasi akan menuju ke long term memory atau akan diteruskan menuju lingkungan berupa respon. Selama proses penyelesaian masalah, di dalam short term memory siswa terjadi pula tahap encoding (penyimpanan informasi dari short term memory ke long term memory). Baik informasi baru yang disimpan atau informasi lama yang disimpan ulang dari short term memory menuju long term memory, sehingga informasi dapat dipanggil kembali pada saat dibutuhkan. Informasi baru maupun informasi lama akan di simpan ulang di long term memory. Dalam penelitian ini, peneliti berasumsi bahwa siswa telah melakukan encoding jika siswa mampu menjelaskan kembali proses pemecahan masalah yang telah dilakukan.

S2 menyelesaikan masalah dimulai dari adanya stimulus berupa informasi. Selanjutnya, stimulus tersebut masuk ke dalam sensory register melalui receptors (alat indra) yaitu indra penglihatan dan indra pendengaran dengan cara membaca soal yang diberikan. Hal tersebut sesuai dengan hasil penelitian Ngilawajan (2013), pada awalnya informasi masuk ke dalam sensory register melalui aktivitas membaca atau dapat dikatakan bahwa aktivitas membaca yang dilakukan menunjukkan bahwa siswa tersebut telah menggunakan indra penglihatannya untuk merekam informasi yang dilihatnya. S2 memberikan attention (perhatian) dengan cara memilah informasi yang ada pada soal agar informasi terfokus. Hal ini sesuai dengan pendapat Prinz yang mengatakan bahwa attention terfokus pada beberapa informasi, dengan memberi perhatian terhadap informasi baru maka informasi tersebut mungkin dapat terhubung dengan pengetahuan yang sudah ada. Dengan demikian, siswa yang berkemampuan matematika sedang dapat membedakan apa yang diketahui dan yang ditanyakan pada soal. Kemudian attention (perhatian) yang terjadi pada S2 dapat terfokus pada stimulus. Selanjutnya akan timbul perception (persepsi). Perception (persepsi) siswa yang berkemampuan matematika sedang adalah masalah yang diberikan berkaitan dengan materi geometri, sehingga untuk menyelesaikan masalah tersebut mereka akan menggunakan phytagoras. S2 kemudian melakukan proses retrieval dengan memanggil kembali informasi atau konsep dari long term memory. Selanjutnya, siswa melakukan rehearsal dengan melakukan pengulangan konsep yang sudah mengalami retrieval tersebut pada short term memory. Ketika S2 sedang melakukan retrieval (pemanggilan kembali), S2 juga mengalami kesalahan konsep. Hal tersebut dikarenakan konsep pada long term memory siswa mengalami fragmented atau tidak saling terhubung. Akibatnya, siswa menjelaskan konsep yang salah atau retrieve failure (kegagalan dalam memanggil informasi yang sudah disimpan) serta telah menyimpan kesalahan tersebut di long term memory. S2 melakukan encoding (penguatan) berupa kelancaran dalam menjelaskan jawaban yang sudah dikerjakan pada saat wawancara, sehingga respon berupa 
jawaban yang diberikan benar. Hasan (2016) mengatakan bahwa proses berpikir siswa akan berjalan dengan benar sebagaimana yang diharapkan jika komponen teori pemrosesan informasi yang ada dari stimulus sampai dengan long term memory pada diri siswa berfungsi dengan baik dan benar pula.

S3 memiliki proses berpikir yang berbeda. Proses berpikir siswa yang berkemampuan matematika rendah dimulai dari adanya informasi berupa soal. Ketika lembar soal diberikan, siswa yang berkemampuan matematika rendah menerima informasi dengan membaca soal yang diberikan. Kemudian informasi berupa soal tersebut masuk ke dalam sensory register. Selanjutnya terjadi attention pada siswa yang berkemampuan matematika rendah. Dengan adanya attention, siswa dapat mengidentifikasi permasalahan yang diberikan. Sehingga siswa dapat mengetahui informasi apa yang diketahui dan apa yang ditanyakan pada soal. Kemampuan siswa dalam menyelesaikan masalah matematika dipengaruhi oleh beberapa hal, antara lain kemampuan siswa dalam mengidentifikasi hal yang diketahui dalam masalah yang diberikan sebagai modal untuk menentukan strategi dan langkah awal. Menurut Gagne, kemampuan individu dalam mengidentifikasi masalah yang diberikan dipengaruhi oleh pengalaman dan pengetahuan dari individu tersebut. Siswa mampu mengidentifikasi informasi yang diberikan, namun siswa salah menafsirkan informasi sehingga tidak sesuai dengan masalah yang diberikan.

Perception (persepsi) S3 adalah menggunakan konsep geometri. Konsep yang digunakan sudah tepat namun dikarenakan siswa tidak tepat dalam mengidentifikasi masalah sehingga penyelesaian pemecahan masalah tidak tepat. Banyak hal yang menyebabkan siswa tidak tepat menyelesaikan masalah, salah satunya dikarenakan pengetahuan dan pengalaman yang terbatas. Selain itu, konsep dan pengalaman yang digunakan untuk merespon stimulus tidak tersimpan dengan baik di memori. Respon siswa yang salah dikarenakan konsep-konsep yang dibutuhkan tidak tersimpan dengan baik di long term memory siswa. Beberapa informasi akan disimpan ulang di long term memory, setelah informasi diproses di short term memory, baik itu informasi yang baru mereka dapatkan atau informasi yang telah mereka dapatkan dan dipanggil kembali.

\section{Kesimpulan}

Berdasarkan hasil penelitian dan pembahasan yang telah diuraikan, maka dapat disimpulkan sebagai berikut:

1. Proses berpikir siswa yang berkemampuan matematika tinggi (S1) dalam menyelesaikan masalah matematika berdasarkan teori pemrosesan informasi dimulai dari adanya informasi atau stimulus berupa soal yang masuk ke dalam sensory register melalui indra penglihatan atau indra pendengaran dengan membaca soal. Kemudian siswa melakukan attention dan memberikan perception. Siswa merealisasikan perception ketika melakukan proses penyelesaian masalah di short term memory dengan melakukan proses retrieval. Siswa melakukan encoding sehingga siswa mampu menjelaskan kembali proses penyelesaian masalah.

2. Proses berpikir siswa yang berkemampuan matematika sedang (S2) dalam menyelesaikan masalah matematika berdasarkan teori pemrosesan informasi dimulai dari adanya stimulus berupa soal yang masuk ke dalam sensory register melalui indra penglihatan dan indra pendengaran. Siswa melakukan attention dan memberikan perception. Ketika melakukan retrieval, siswa yang berkemampuan matematika sedang ada yang mengalami kesalahan atau retrieval failure sehingga siswa tersebut telah menyimpan kesalahan konsep di dalam long term memory.

3. Proses berpikir siswa yang berkemampuan matematika rendah (S3) dalam menyelesaikan masalah matematika berdasarkan teori pemrosesan informasi dimulai dari adanya stimulus berupa soal yang masuk ke dalam sensory register melalui indra penglihatan, indra pendengaran, dan indra perabaan. Siswa melakukan attention dan memberikan perception. Ketika melakukan perception, siswa yang berkemampuan matematika rendah mengalami kesalahan dan lupa. Hal ini karena konsep-konsep yang dibutuhkan short term memory tidak tersimpan dengan baik oleh long term memory.

\section{DAFTAR PUSTAKA}

Bogdan. R. C, Biklen. S. K. 1982. Qualitative Research For Education: An Introduction To Theory And Methods. Boston London: Allyn And Bacon, Inc.

Creswell. W. J. 2012. Education research: Planning, conducting and evaluating quantitative and qualitative research fourth edition. Boston: Pearson., inc.

Hasan. B. 2016. Proses Berpikir Mahasiswa dalam Mengkonstruksi Bukti Menggunakan Induksi Matematika Berdasarkan Teori Pemerosesan Informasi. Apotema, 2(1): 33-40.

Imelda. 2018. Analisis Kesulitan Mahasiswa dalam Menyelesaikan Soal Pemecahan Masalah pada Mata Kuliah Aljabar dan Trigonometri. Journal of Mathematics Education and Science, 4(1): 49-60

Indah. M EB. 2016. Analisis Proses Pemecahan Masalah Geometri Berdasarkan Teori Van Hiele di Sekolah Menengah Atas. Noken, 2(1): 28-39.

Jeneson. A, Squire. L. R. Working Memory, Long Term Memory and Media Temporal Lobe Function, doctoral diss., University of California, San Diego, 2012

Lilijedahl. P, Santos-Trigo. M, Malaspina U, Bruder. R. 2016. Problem Solving in Mathmatics Education. Hamburg. 
Matlin. M. W. 2009. Cognition. Seventh Edition. John Wiley \& Sons, Inc

Ngilawajan. D.A. 2013. Proses Berpikir Siswa Smadalam Memecahkan Masalah Matematika Materi Turunan Ditinjau Dari Gaya Kognitif Field Independent Dan Field Independent. Pedagogia, 2(1): 71-83

Novriyani. M. R, Suya. E. 2017. Analysis of Student Difficulties inMathematics Problem Solving Ability at MTs swasta IRA Medan. International Journalof Sciences Basic and Applied Reserch. 63-75

Putra, D.B.P. Proses Berpikir Siswa dalam Menyelesaikan Persamaan Trigonometri Sederhana Ditinjau dari Teori Pemrosesan Informasi. Tesis, Universitas Negeri Malang, Malang, 2014.

Polya. 1973. How To Solve It A New Aspect of Mathematical Method. Princeton University Press: New Jersey

Solso, Robert L., et al. 2008. Psikologi Kognitif Edisi ke 8 (alih bahasa Mikael Rahardanto dan Kristanto Batuadji. Jakarta : Erlangga

Susanto. A. 2013. Teori Belajar dan Pembelajaran di Sekolah Dasar. Jakarta: Kencana Prenada Media Group

Syaiful, Muslim, Huda. N., et al. 2019. Comunication Skill And Mathematical Problem Solving Ability Among Junior High Schools Student Thourgh Problem Based Learning. International Journal Of Scientific \& Technology Reserch. 8(11): 1048-1060

Amamah, S. Proses Berpikir Siswa SMP Fiels Dependent dan Field Independent dalam Menyelesaikan Masalah Bangun Datar Ditinjau dari Teori Pemrosesan Informasi. Tesis, Universitas Negeri Malang, Malang, 2016.

Wang.Y, Chiew. V. 2010. On The Cognitive Process Of Human Problem Solving. Cognitive system reserch.11(2010): 81-92. 